\title{
CAPABILITY' DEVELOPMENT THROUGH ICT ENABLED BUSINESS OPPORTUNITY DEVELOPMENT MODEL OF E-CHOUPAL
}

\author{
Pankaj MADAN ${ }^{1}$, Vinay SHARMA ${ }^{2}$, Piyush SETH $^{3}$ \\ ${ }^{1}$ Centrum Católica, Pontificia Universidad Católica del Peru, Surco, Lima 33, Peru \\ ${ }^{2}$ Department of Management Studies, Indian Institute of Technology, \\ Roorkee, Uttarakhand, India \\ ${ }^{3}$ Department of Computer Science, Feroz Gandhi Institute \\ of Engineering and Technology,Raebareli, India \\ E-mails: 1pmadan@pucp.edu.pe (corresponding author); \\ 2 vinayfdm@iitr.ac.in; 3 piyush21oct@rediffmail.com \\ Received 13 February 2012; accepted 05 November 2012
}

\begin{abstract}
The purpose of this study is to check how ICT led business opportunity development model of ITC e-Choupal affected "Capability" development of the people in rural India. The survey of three different regions of India, included 319 e-Choupal beneficiaries and 10 ITC officials and elected representatives of villages. Statistical analysis revealed that Capability Enhancement of farmers depended on the extent to which farmers trusted and participated in ICT activities that varied based on their education level but specifically e-Choupal could generate only limited business opportunities for rural masses. However, the business opportunities definitely affected the capability enhancement parameters. The ICT enabled business models can be well used by corporates and governments of developing economies in Asia and Africa for capability development of rural masses as these models provide new business opportunities for them. The field survey based framework showed how ICT based business opportunity development model of e-Choupal can affect the income, time and saving of farmers in developing economy.
\end{abstract}

Keywords: ICT, business opportunity development, capability, ITC, e-Choupal, rural.

JEL Classification: B15, C12, D11, D63, E24, I3, L21, O12.

\section{Introduction}

Developing economies have unrivaled opportunities and these opportunities can be capitalized through information and communication technologies (ICTs) as it has the technical prospect to offer tools for idea generation, idea propagation and recognition, which can further enhance the efficiency of educational systems, improve the health care systems and execution of policy formulation, enlarge the choices of prospects for income creation, increase the participation of masses in the democratic process and political issues, and bring about a social change amongst the poor and rural people. Today most of the companies are looking forward to rural markets and are emphasizing 
up on the increase of the real income of rural people by providing expanded market or new horizons of business opportunities through ICT. ICT is providing new dimensions or alternative business opportunity which plays major role for the present and future aspects of the development of rural people. The paper analyses ITC e- initiative, based on ICT led business model "e-Choupal" (refer Fig. 1), which enables Indian agriculture significantly to enhance its competitiveness by empowering Indian farmers through the power of the Internet which can develop the "Capability" (Sen 2000) of the rural people and has been designed to tackle the challenges created by the unique features of Indian agriculture, characterized by fragmented farms, weak infrastructure and the involvement of many intermediaries, among others to create buying power and develop the market at bottom of pyramid. Launched in June 2000, ITC's e-Choupal (ITC 2012) now has reached out to more than 4 million farmers growing a range of crops soyabean, coffee, wheat, rice, pulses, and shrimp in over 40,000 villages through 6500 kiosks across 10 states. The model is centred on a network of e-Choupals that serve both as a social gathering place for exchange of information and an e-commerce hub. It makes use of the physical transmission "Capabilities" of current intermediaries, aggregation, logistics, counter-party risk and bridge financing while disinter mediating them from the chain of information flow and market signals. With a judicious blend of click and mortar capabilities, village internet kiosks managed by farmers called Sanchalaks (e-Choupal operators) themselves, enable the agricultural community to access ready information in their local language on the weather and market prices, disseminate knowledge on scientific farm practices and risk management, and also facilitate the sale of farm inputs (now with embedded knowledge) and purchase farm produce from the farmers doorsteps (decision making is now information-based). ITC has plans to saturate the sector in which it works with e-Choupals, such that a farmer has to travel no more than five

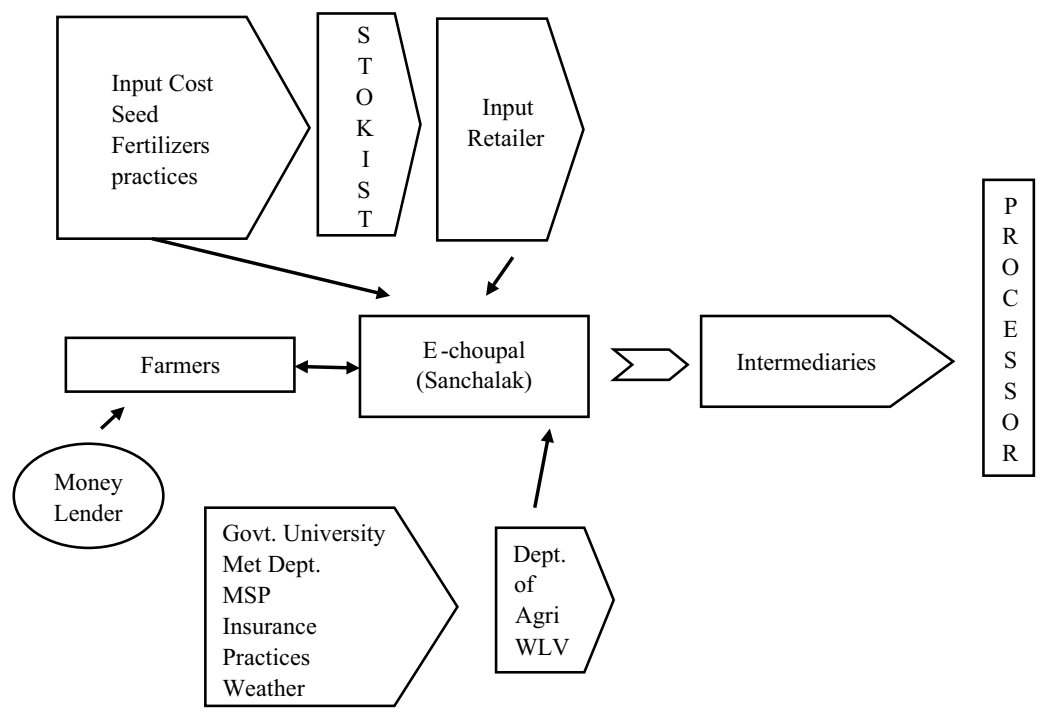

Fig. 1. E-Choupal, a new business model

Source: Bowonder et al. (2015). 
kilometers to reach one. Two goals were envisioned for information technology in the e-Choupal process. The first was the delivery of real-time information independent of the transaction. In the "mandi" (wholesale market for commodities at city level) system, delivery, pricing, and sales happen simultaneously, thus binding the farmer to a mandi agent. E-Choupal was seen as a medium of delivering critical market information independent of the mandi, thus allowing the farmer an empowered choice of where and when to sell his crop.

The services provided by e-Choupal include selling of consumer goods to farmers, providing loans and facilitating loan from other banks, life insurance and crop insurance, updates on weather forecast. The e-Choupal website prominently displays ITC procurement rate and the local "mandi" rates for various commodities and publishes next day rates every evening. Latest pricing information help local farmers to make informed decision about better sale price for his produce to get high profits. It circulates crop specific and location specific traditional wisdom by virtue of farmer's long farming experience and understanding of local situation in the form of crop-specific best practices that remained un-documented in the past. It enables farmers to bring their specific problems or questions to scientists or expert's attention via e-mails, teleconferencing etc. who provide better solutions to farmers after careful examination and assessment. It not only provides best quality seeds, fertilizers, pesticides etc. for major seasonal crops as per their demand but also make them aware about "how to use" and do free testing for soil sample brought by farmers to catalyze their agricultural practices. ITC through its website e-Choupal also purchases the harvested produce of farmers so that farmers get appropriate price of their produce. Although it was not mandatory for e-Choupal users to offer their produce, yet many farmers found it profitable and hassle-free. The payment by ITC was also quick and straightforward.

\section{An overview of the literature}

Elaborating on the fundamental concept which influences this study, Sen (1983) said that traditional economics have failed to identify the components which will give a path to the economic growth and the authors of the current study realized that this can be the major reason for prevailing poverty and hunger in many developing economies in Asia and Africa. Szirmai (2005) focused on the problems of widespread poverty, hunger and misery in developing countries and on the question of what can be done in order to realise improvements of the situation in the short term. Dreze and Sen (1995) stressed upon the basic education of people for economic growth, though it may take a long time for being so. Haq (1995) in his study stated that economic growth depends on the quality and distribution of economic growth and not only on the quantity of such growth. The author has propounded that a link between income growth and human welfare has to be created consciously through public policies which aim at providing services and opportunities as equitably as possible to all citizens. He has also asserted that this cannot be left to the market mechanisms, because these are essentially very unfriendly to the poor, to the weak, and to the vulnerable. Avgerou (2000) in his study stated that there is an unquestioned notion about ICT that investing in it gives assurance 
of social and economic development both. Moreover, ICT has the technical potential to offer tools for idea generation, idea propagation and recognition. Martinussen (1996) emphasised that the core of human development comprises the enlargement of people's choices, welfare and equitable access to opportunities, it is deemed expedient to make a distinction between, management of public resources for human development, and the creation of an enabling environment for people's participation and the exercising of choices. Further, the study provides a framework for analyses and development, cooperation which is basically different from the paradigm associated with conceptions of development as growth. Sen (2000) stated in his study that freedom is not only the primary end of development but they are also among its principal means. Moreover, he describes unfreedoms which, occurs in the form of famine, malnutrition, limited access to health care, poverty, and premature mortality can be removed by development. Prahalad and Hammond (2002) stated that the freedom of development for poor people can create massive market at the "Bottom of the Pyramid" (BoP) and in present era many of the businesses aimed to target the consumers at the "bottom of the pyramid" by providing social and economic infrastructure. If they are customer and develop their capability through the usage of Information and Communication Technology which will create the buying power at bottom of pyramid and converts this stratum into a market as well as social development. Sharma et al. (2011) revealed in their study that, how ICT can create the buying power at the BoP and convert this level into a market and achieve social development as well. ITC implemented their unique business venture e-Choupal so as to develop the capability of its customer by providing freedom, however projects like TATA literacy that cannot develop the market directly but unquestionably develops there capability. Oosterlaken et al. (2009) explained about how "Capability" and technology play key role in the development process of humans. Sen (2000) also argued that ICT expands the opportunities of the business development and patronize the reduction of inequality of freedom of market transactions, which will unswervingly enhance the "Capability" of rural people. Nussbaum (2003) in his article supported Sen's idea arguing that capabilities supply guidance superior to that of utility and resources, but also to that of social contract tradition and some accounts of human rights. Sen (1984) pointed out "Capability" as the notion of a good (rice), the characteristics of the good (calories and nutrition); the functioning of a person (living without calorie deficiency); that of utility (the pleasure of desire fulfilment). Similarly, using ICT and enhancing knowledge can be considered as the capability approach, "ICT is a good, and information is it's characteristic, functioning is the management of knowledge and information by the individuals and the community and utility is the conversion of knowledge into social and economic returns". The freedom of expanding the "Capability" refers to the development of rural population including literacy with education, leading healthy lifestyle, improvement in financial and social conditions by participation in business activities, access to jobs and market. Usage of ICT improve access of information and knowledge on the beneficiaries' side, which can enhance the "Capabilities" of rural people that makes "strategic life choices and to achieve the life style they value". Further, Kabongo and Okpara (2014) in their study demonstrated that nearly 51 percent of SMEs in the sample reported a cell phone number, making this ICT tool the most popular among 
SMEs studied in the developing economy of the Democratic Republic (DR) of the Congo. Gigler (2004). Garai and Shadrach (2006) highlighted that the potential of information and knowledge can change the entire scenario of the country. The information and knowledge by ICT can develop rural community by facilitating through appropriate tools of communication. Deen-Swarray et al. (2013) resulted from their study in Africa that ICTs may allow for a deepening of the distribution and procurement channels of business. Doing business over distance could become more affordable through the mobile phone and mobile money.

\section{Objectives of the study}

The main aim of this research was to conduct a study of business opportunity development interventions through e-Choupal on the "Capability" development of rural people in Uttar Pradesh. This research is a comprehensive study in the sense that it identified parameters of "Capabilities" of the rural people in India, made an appraisal of the functioning of e-Choupal and analyzed its impact on the economic and "Capability" development of the rural population in Uttar Pradesh. Needless to mention that the tasks for identifying the parameters of "Capability" of rural people were kept in mind. It also illustrate how the starting conditions (characteristics) constrains the "Capabilities" via personal, social and environmental factors (Good, Qureshi 2009).

The objectives of the research can be enumerated as follows:

a. To find out the awareness of rural people about "Capability" development issues.

b. To make an estimation of trust and participation of rural people on e-Choupal vis-à-vis other similar programmes.

c. To analyse various aspects of "Capability" approach and business opportunity development by e-Choupal and establish relationship thereof.

d. To analyse the impact of e-Choupal on "Capability" development of the rural population.

\section{Conceptual framework and research approach}

The reasons for taking the concept of "Capability" as a measurement scale is that this approach suggests that development should not only be evaluated in quantitative terms like reducing the poverty, income generation etc. but also to be evaluated with respect to substantive freedoms that people have to achieve through alternative combination of functioning. This concept recommends the real changes in the being of a person with reference to his/her own desires. The approach of the study emerged from its underlying thought aptly explained by its subject and title which says that the proponents wished to study the "Effects of ICT (Information and communication technology) enabled business development opportunities on the 'Capability' development of rural people with reference to e-Choupal", implying that the study was looking for "Capability" conceptually customized if at all required with the support of the parameters those would be suggested by the target farmers (respondents).

The study adopted the following basic sequence: 


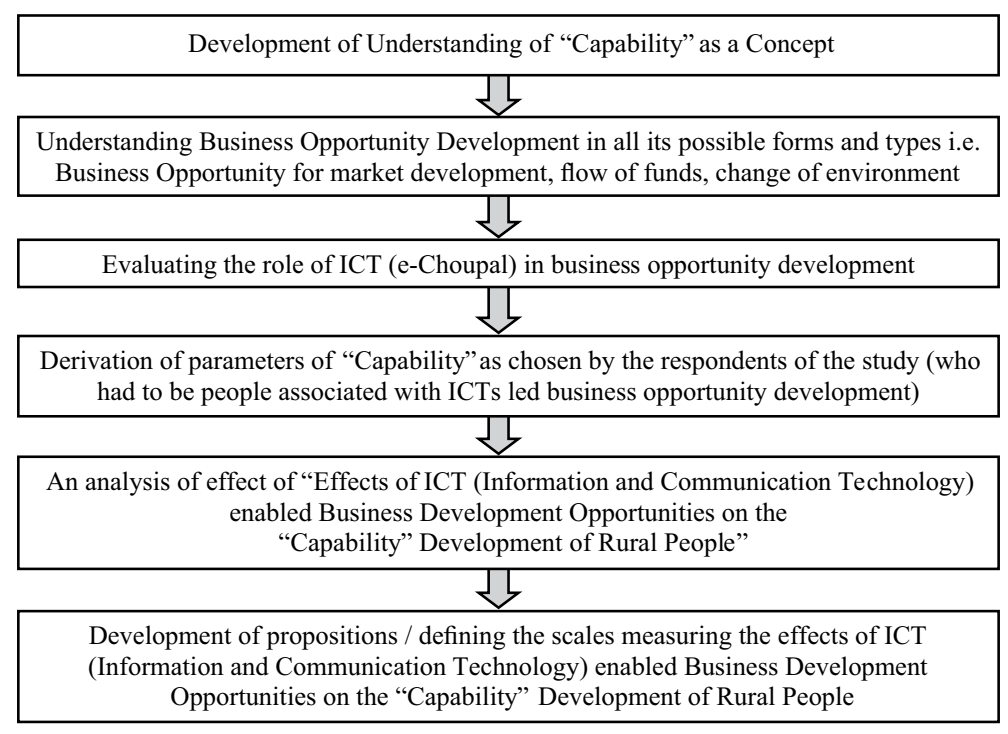

Fig. 2. Flow chart of the study

The study was conducted in two phases wherein the first phase was related to establish the parameters/influencers of "Capability" based on factors retrieved from literature review, observations and interviews while conducting initial field survey. This exploration simply allowed for an in-depth understanding of the concept and to identify the significant variables to be studied. "Capability means adequacy, capacity and potential to live life efficiently, effectively and successfully the way we want to live" said most of the farmers during their interview response. Another farmer said that they should be able to avail the basic amenities, facilities and convenience that are necessary to live better life. He said, better education system for kids, avoidance of dual policy for rich and poor, improved economic and social status of life, good health facilities are vital for their growth and development.

After identifying the parameters, they were used in constructing the questionnaires (refer Table 1) for farmers as respondents. The pilot testing for questionnaire validity was done in two districts on 55 respondents. In the first phase of the final study, the researcher's discussions with respondents lead to an understanding in relation to their concept of "Capability" in relation to e-Choupals they are associated with for the services. This round of discussions was directed towards knowing their "Capability" development levels by providing business opportunity to the respondents by e-Choupal in which they also themselves suggested to the parameters of the services and showed their level of "Trust and Participation" in ICT based project e-choupal (refer Table 1). The reliability test of 72 such items gave Cronbach's Alpha value of 0.893 . The second phase started with collection of the information and understanding of the respondents' behaviour with respect to "Capability" development through the "business opportunities" (refer Table 1) developed by ICT based project through descriptive research design. Sample size taken was 319 respondents consisting of e-Choupal beneficiaries and 10 officials of ITCs 
officials, Sanchalaks and Gram Pradhans (Elected heads of the village also known as Sarpanch). Surveys about the parameters of "Capability" and the standards of the services they perceived were done. The initial round of the discussion and the questions put forward were directed to test the purpose for which respondents take help of e-Choupal in their daily lives. The second round of questions were intended to gain an understanding towards the proportional impact of e-Choupal had on income, time and savings of respondents i.e. are they getting benefited from e-Choupal? Finally the third session of the questions tried to find out that if the ICT based business opportunity development provided to the respondents, was able to affect their "Capability". The questions were directed towards measuring their capability development levels by adding attributes and surveys were conducted in 3 different regions of the state of Uttar Pradesh based on clustered random sampling. The method adopted (refer Fig. 2) was that, the villagers were collected at one place with the help of Sanchalaks, Gram Pradhans (elected village heads) and a local ITC officials to get their data. Further, the aspect of research was always instigated in an informal manner and then was taken to deeper levels, whereas small groups ( 8 people at a time) were formed. Each discussion took more than 3 hours. The details of the variables and the related items are summarized in Table 1.

Table 1. Summary of variables and items

\begin{tabular}{|c|c|}
\hline Variables (components) & Items \\
\hline $\begin{array}{l}\text { Trust and Participation } \\
\text { (Independent) }\end{array}$ & $\begin{array}{l}\text { Information on market price, agricultural } \\
\text { fiend and technology, health, jobs, education, } \\
\text { work, news, entertainment and training }\end{array}$ \\
\hline $\begin{array}{l}\text { Business Opportunity Development (Market, } \\
\text { Technology, News, Education, Work, Job, } \\
\text { Health) } \\
\text { (Independent) }\end{array}$ & $\begin{array}{l}\text { Importance of information } \\
\text { Extent of influence in last five years }\end{array}$ \\
\hline $\begin{array}{l}\text { Capability Development (Education, Health, } \\
\text { Business confidence, Socio-economic status) } \\
\text { (Dependent) }\end{array}$ & $\begin{array}{l}\text { Education perspective } \\
\text { Health } \\
\text { Business confidence } \\
\text { Socio-economic status }\end{array}$ \\
\hline
\end{tabular}

\section{Results and data interpretation}

The bar chart below depicts the respondents' classification about the extent the usage of e-Choupal has influenced each of the beneficiaries over last 5 years.

Farmers felt that in last 5 years the e-Choupal had a largely influenced their sales (refer Fig. 3) and enabled quick turnover, saved time and cost on travel, provided information on crop, new products, live stock, moderately increased their speed of communication but influenced comparatively less on cost reduction, legal rights on water and land, school education (refer Fig. 4), family health information (refer Fig. 5). The bar charts below depict the role of ICT based business opportunity development and its impact on the "Capability" Sen (2000) parameters. 
a)

\begin{tabular}{|l|l|l|c|c|c||}
\hline & \\
\hline
\end{tabular}

b)

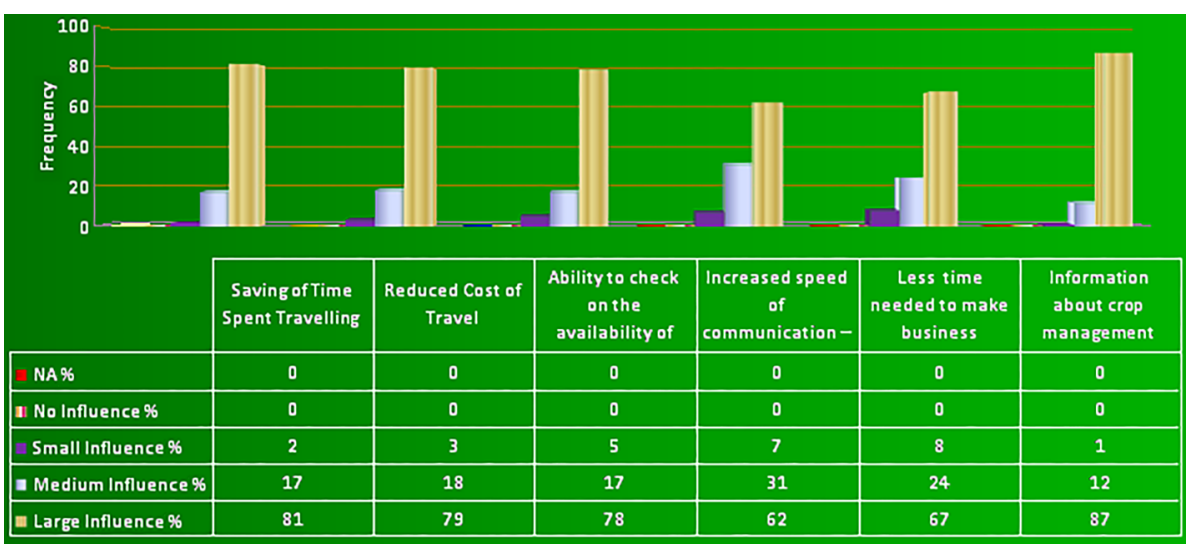

c)

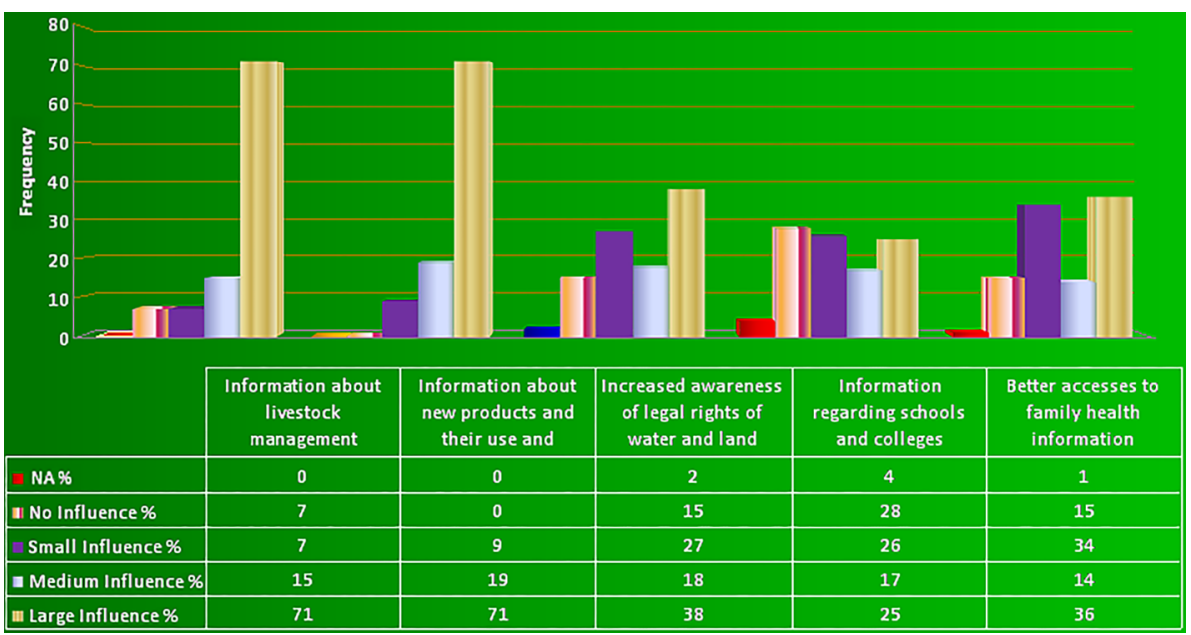

Fig. 3. Respondents classification on the basis of extent of influence of e-Choupal in last 5 years 


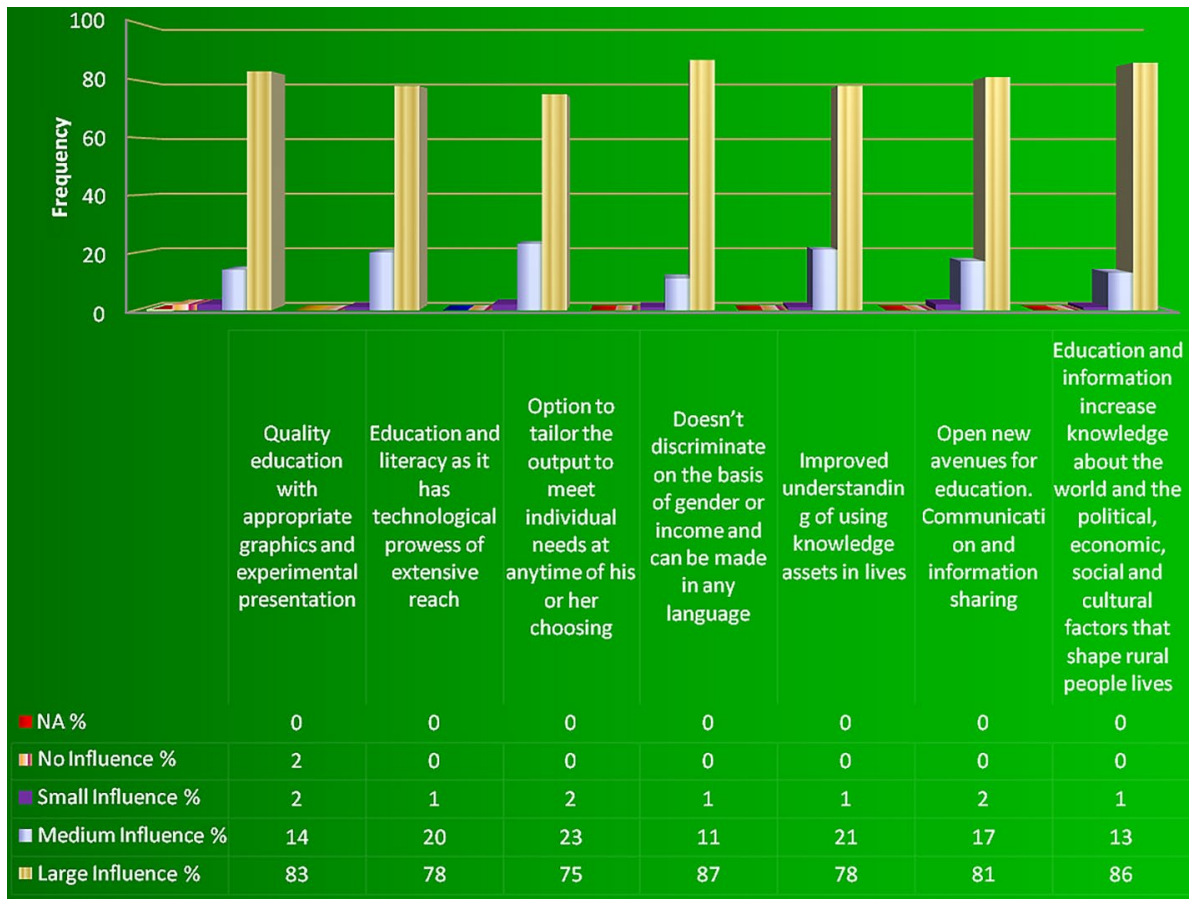

Fig. 4. Respondents classification on the basis of ICT based business opportunity development and its impact on education perspective

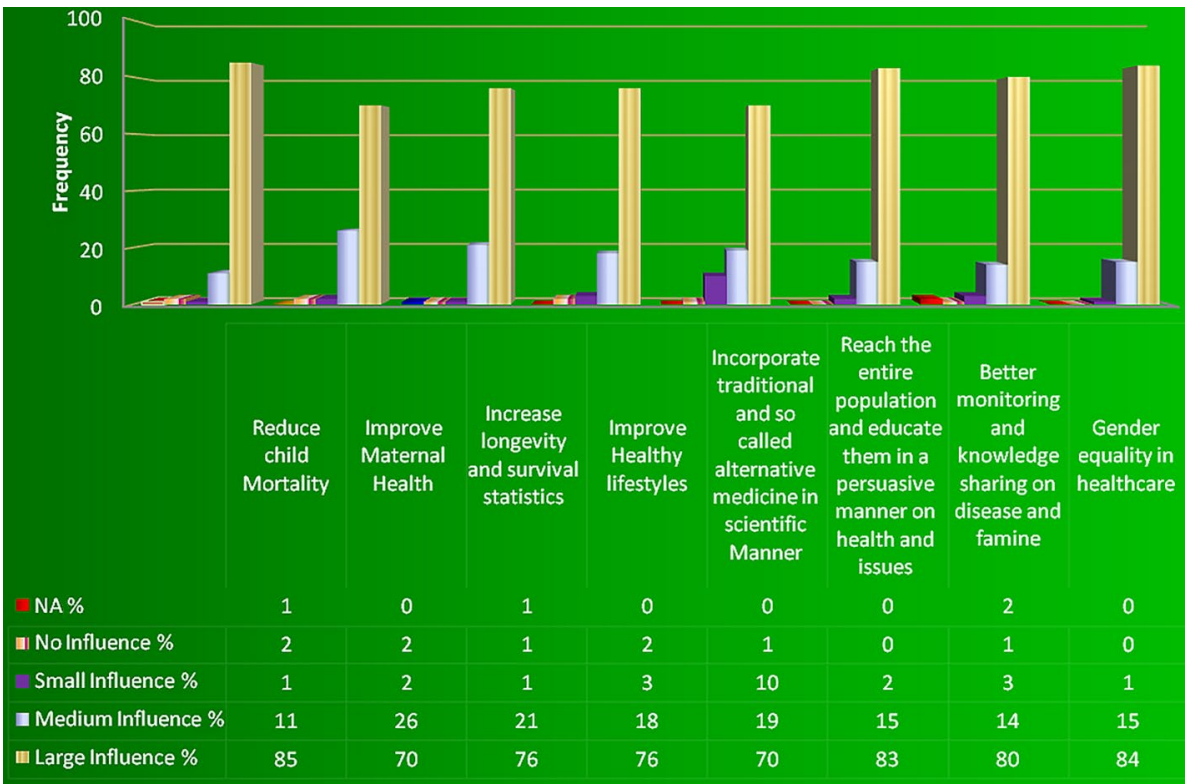

Fig. 5. Respondents classification on the basis of ICT based business opportunity development and its impact on health perspective 
Farmers responded that ICT based business opportunity had a largely influenced their health and health related issues, increased their confidence to travel, interact, communicate and make more contacts (refer Fig. 6) and reduced their exploitation, improved their ability to analyze the situation and solve their problems (refer Fig. 7), increased their access to regional, national and global markets.

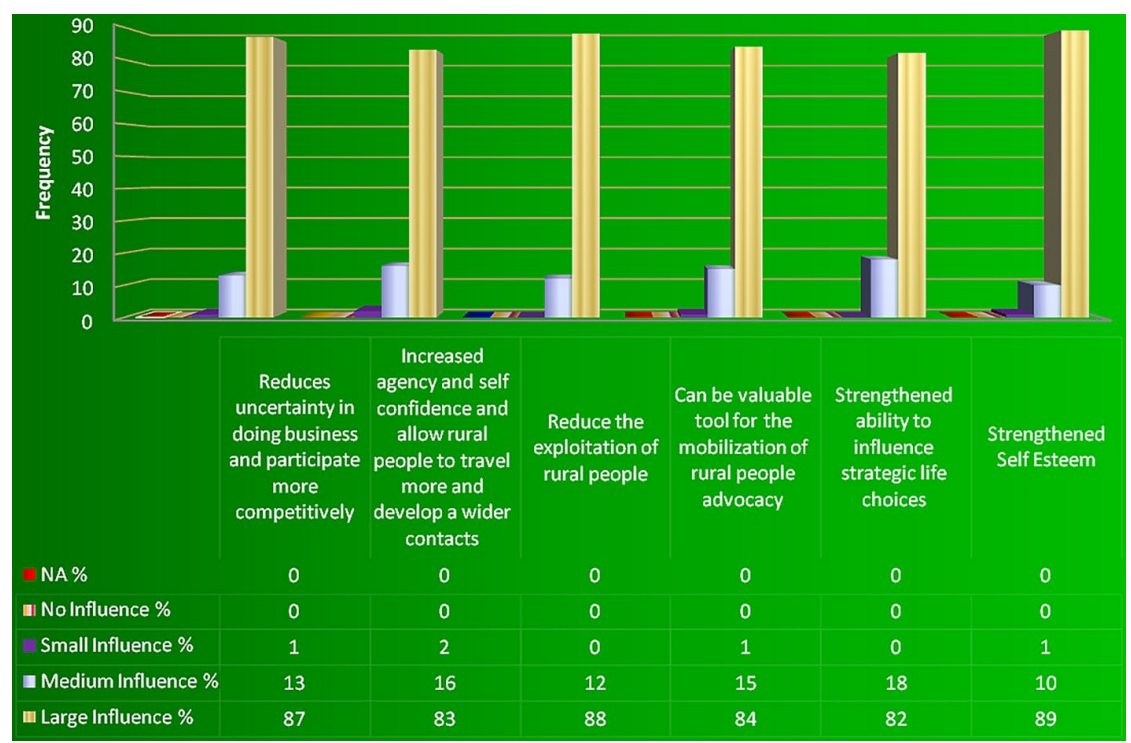

Fig. 6. Respondents classification on the basis of ICT based business opportunity development and its impact on psychological perspective

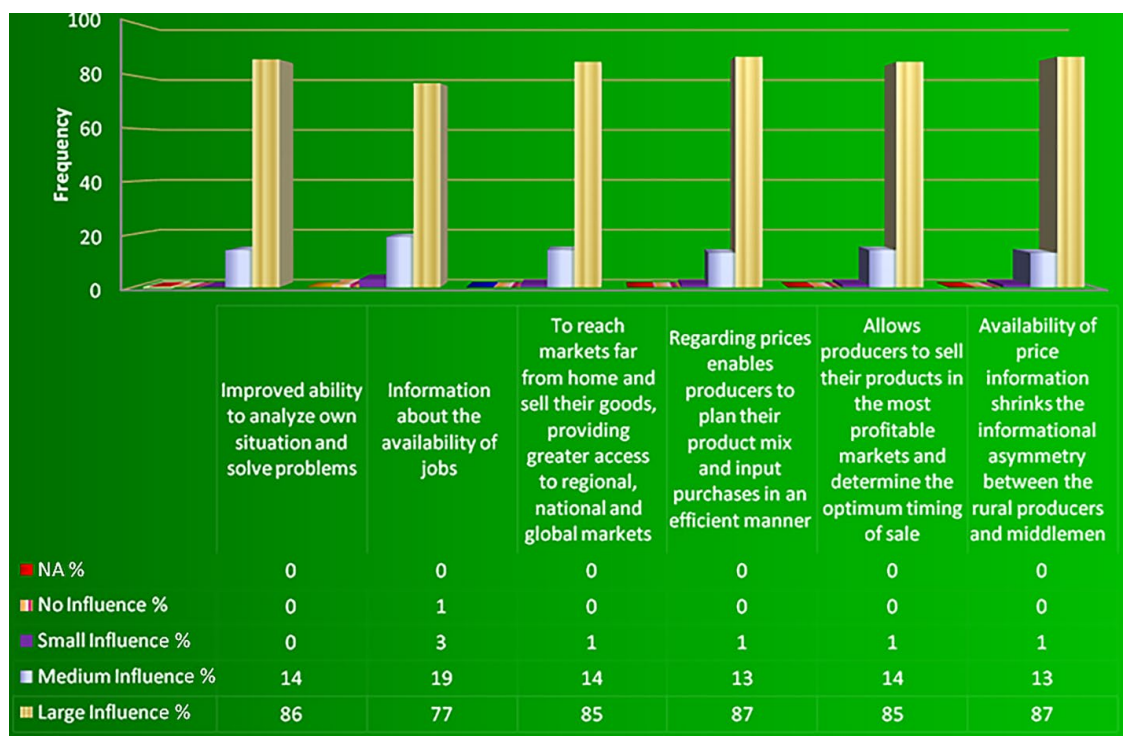

Fig. 7. Respondents classification on the basis of ICT based business opportunity development and its impact on socio-economic perspective 
H1: rural people have trust and participate in e-Choupal activities for enhancing their "Capability" level.

Table 2. Chi-Square test of independence between participation in e-Choupal and Capability Enhancement

\begin{tabular}{lccc}
\hline & Value & df & Asymp. Sig. (2-sided) \\
\hline Pearson Chi-Square & $23.334(\mathrm{a})$ & 4 & .000 \\
\hline Likelihood Ratio & 15.624 & 4 & .004 \\
\hline Linear-by-Linear Association & 13.187 & 1 & .000 \\
\hline N of Valid Cases & 319 & & \\
\hline
\end{tabular}

Table 2 Chi-Square measures test the hypothesis that the row and column variables in a cross tabulation are independent or not. Above table contains the output of the ChiSquare test. df equals the number of categories minus one. A low significance value $(0.000,0.004$ and 0.000$)$ indicates that there may be some relationship between the two variables:

$$
\begin{aligned}
& \mathrm{X}_{\mathrm{cal}}^{2}=23.334, \mathrm{X}_{\mathrm{tab}(4,0.05)}^{2}=9.488, \\
& \text { since } \mathrm{X}_{\mathrm{cal}}^{2}>\mathrm{X}_{\mathrm{tab}}^{2} .
\end{aligned}
$$

It is evident from Chi-Square test that variables "Trust and Participation" and "Capability Enhancement" are related and capability enhancement is dependent on the extent to which farmers trust and participate in e-Choupal activities. Hence we accept the hypothesis at $5 \%$ level of significance. Using the Chi-Square test procedure (1), it is found that the capability enhancement is not constant among the people who trusted and participated in e-Choupal and those who don't. This is due to variation in the respondents who feel that participation in e-Choupal has largely influenced their capability and others who differ in view but largely dependence of capability enhancement of farmers on trust and participation in e-Choupal activities has been proved.

H2: e-Choupal developed significant business opportunities for the rural masses.

\begin{tabular}{|c|c|c|c|c|c|c|}
\hline & \multicolumn{6}{|c|}{ Test value $=78$} \\
\hline & \multirow[t]{2}{*}{$\mathrm{T}$} & \multirow[t]{2}{*}{ Df } & \multirow[t]{2}{*}{$\begin{array}{c}\text { Sig. } \\
\text { (2-tailed) }\end{array}$} & \multirow[t]{2}{*}{ Mean difference } & \multicolumn{2}{|c|}{$\begin{array}{l}\text { 95\% Confidence interval of the } \\
\text { difference }\end{array}$} \\
\hline & & & & & Lower & Upper \\
\hline $\begin{array}{l}\text { Business } \\
\text { opportunities }\end{array}$ & 6.913 & 318 & .000 & -2.727 & -3.50 & -1.95 \\
\hline
\end{tabular}

Table 3. One-sample test of business opportunities

The One-Sample T Test procedure tested whether the mean of a single variable Business Opportunities differs from a specified constant. A low significance value 0.000 (typically below 0.05 ) in Table 3 indicates that there is a significant difference between the test value and the observed mean. The confidence interval for the mean difference does not contain zero as the lower value is -3.50 and the upper is -1.85 also indicates that the difference is significant. As the significance value is low and the confidence interval for 
the mean difference does not contain zero, we can conclude that there is a significant difference between the test value and the observed mean.

$$
\begin{aligned}
& \mathrm{T}_{\text {cal }}=-6.913 \text { and } \mathrm{T}_{\mathrm{tab}}=1.645, \\
& \text { since, } \mathrm{T}_{\mathrm{cal}}<\mathrm{T}_{\mathrm{tab}} .
\end{aligned}
$$

It is evident from $\mathrm{T}$ test result (2) that data set obtained by the researcher indicates that tested value is not significant. Hence we reject the hypothesis at 5\% level of significance.

H3: Business development opportunity affects the components of "Capability".

Table 4. Correlation of business development opportunities and parameters of capability enhancement

\begin{tabular}{lccc}
\hline & & $\begin{array}{c}\text { Business development } \\
\text { opportunities }\end{array}$ & $\begin{array}{c}\text { Parameters of capability } \\
\text { enhancement }\end{array}$ \\
\hline $\begin{array}{l}\text { Business Development } \\
\text { Opportunities }\end{array}$ & $\begin{array}{c}\text { Pearson } \\
\text { Correlation }\end{array}$ & 1 & $.601^{* *}$ \\
\hline & Sig. (2-tailed) &. & .000 \\
\hline & $\mathrm{N}$ & 319 & 319 \\
\hline $\begin{array}{l}\text { Parameters of Capability } \\
\text { Enhancement }\end{array}$ & $\begin{array}{c}\text { Pearson } \\
\text { Correlation }\end{array}$ & $.601^{* *}$ & 1 \\
\hline & Sig. (2-tailed) & .000 & 319 \\
\hline & $\mathrm{N}$ & 319 & \\
\hline
\end{tabular}

Note: ** Correlation is significant at the 0.01 level (2-tailed).

Table 5. Regression model summary of business development opportunities

\begin{tabular}{cccccccccc}
\hline Model & $\mathrm{R}$ & $\mathrm{R}$ square & $\begin{array}{c}\text { Adjusted } \\
\mathrm{R} \text { square }\end{array}$ & $\begin{array}{l}\text { Std. error of } \\
\text { the estimate }\end{array}$ & \multicolumn{3}{c}{ Change statistics } & \\
\hline & & & & $\begin{array}{c}\text { R square } \\
\text { change }\end{array}$ & F change & df1 & df2 & $\begin{array}{c}\text { Sig. F } \\
\text { change }\end{array}$ \\
\hline 1 & $.60^{\mathrm{a}}$ & .361 & .359 & 6.100 & .361 & 179.226 & 1 & 317 & .000 \\
\hline
\end{tabular}

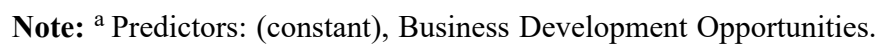

Table 6. ANOVA ${ }^{\mathrm{b}}$

\begin{tabular}{ccccccc}
\hline Model & & Sum of squares & Df & Mean square & F & Sig. \\
\hline 1 & Regression & 6668.248 & 1 & 6668.248 & 179.226 & $.000^{\mathrm{a}}$ \\
\hline Residual & 11794.223 & 317 & 37.206 & & \\
\hline Total & 18462.470 & 318 & & & \\
\hline
\end{tabular}

Notes: ${ }^{a}$ Predictors: (constant), Business Development Opportunities; ${ }^{b}$ Dependent variable: Parameters Of Capability Enhancement. 
Table 7. Correlation coefficients ${ }^{\mathrm{a}}$ of Business Development Opportunities

\begin{tabular}{clcccrr}
\hline \multirow{2}{*}{ Model } & & \multicolumn{2}{c}{$\begin{array}{c}\text { Unstandardized } \\
\text { coefficients }\end{array}$} & $\begin{array}{c}\text { Standardized } \\
\text { coefficients }\end{array}$ & T & Sig. \\
\hline 1 & B & Std. error & Beta & & \\
\hline & & 55.725 & 5.487 & & 10.156 & .000 \\
\hline & $\begin{array}{l}\text { Business Development } \\
\text { Opportunities }\end{array}$ & .623 & .046 & .601 & 13.388 & .000 \\
\hline
\end{tabular}

Note: ${ }^{\text {a }}$ Dependent variable: parameter of Capability Enhancement.

The correlations Table 4 displays Pearson correlation coefficients (between two variables, business development opportunities and parameters of capability enhancement), significance values, and the number of cases with non-missing values. Pearson correlation coefficients assume the data are normally distributed. The absolute value of 0.610 of the correlation coefficient indicates its strength; with larger absolute values $(0.610>$ $0.50)$ indicating moderately stronger and positive relationship between the two. Correlations above the main diagonal are mirror images of those below. The significance of each correlation coefficient is also displayed in the correlation Table 4. The significance level (or p-value) is the probability of obtaining results as extreme as the one observed. Since the significance value here is .000 the two variables are significantly positively correlated. Regression Table 5 displays R, R squared, adjusted R squared, and the standard error. $\mathrm{R}$, the multiple correlation coefficients, is the correlation between the observed and predicted values of the dependent variable. The values of $R=0.601$ for models produced by the regression procedure range from 0 to 1 . Larger values of $\mathrm{R}$ indicate stronger relationships. $\mathrm{R}$ squared is the proportion of variation in the dependent variable explained by the regression model. The values of $\mathrm{R}$ squared $=0.318$ range from 0 to 1 . Small values indicate that the model does not fit the data well. The sample R squared tends to optimistically estimate how well the model fits the population. Adjusted R squared $=0.359$ attempts to correct $\mathrm{R}$ squared to more closely reflect the goodness of fit of the model in the population. The ANOVA Table 6 summarizes the results of an analysis of variance. The sum of squares, degrees of freedom, and mean square are displayed for two sources of variation, regression and residual. The output for regression $=6668.248$ displays information about the variation accounted for by our model. The output for residual $=11794.223$ displays information about the variation that is not accounted for by our model. And the output for total is the sum of the information for regression and residual. High residual sum of squares (11794.223 > 6668.248) indicate that the model fails to explain a lot of the variation in the dependent variable, and we may want to look for additional factors that help account for a higher proportion of the variation in the dependent variable. The mean square is the sum of squares divided by the degrees of freedom. The $\mathrm{F}=179.226$ is the regression mean square (MSR) divided by the residual mean square (MSE). The regression degrees of 
freedom is the numerator $\mathrm{df}$ and the residual degrees of freedom is the denominator $\mathrm{df}$ for the F statistic. The total number of degrees of freedom is the number of cases minus 1. Although, the residual value is higher than the regression value yet the small significance value of $\mathrm{F}$ that is 0.000 (smaller than say 0.05) makes the independent variables (business development opportunities) do a good job explaining the variation in the dependent variable capability enhancement. In Table 7, the un-standardized coefficients are the coefficients of the estimated regression model. In this estimated model the parameters of capability enhancement $=55.725-0.623$ business development opportunities. The standardized coefficients $=0.601$ or betas are an attempt to make the regression coefficients more comparable. The $\mathrm{t}=13.338$, which is more than +2 makes the value of regression more significant.

H4: There is a significant difference in Participation level of people in e-Choupal based on their education.

Table 8. ANOVA (Participation in e-Choupal)

\begin{tabular}{lccccc}
\hline & Sum of squares & df & Mean square & F & Sig. \\
\hline Between Groups & 12.895 & 4 & 3.224 & 4.433 & .002 \\
\hline Within Groups & 228.377 & 314 & .727 & & \\
\hline Total & 241.273 & 318 & & & \\
\hline
\end{tabular}

The difference in Participation of people (with different education qualification) using e-Choupal is tested through One-way ANOVA. The standard deviation indicated the amount of variability of the scores in each group. Equality is inspected via the Levene test. The results of the analysis are presented in an ANOVA Table 8, the total variation is partitioned into two components. Between groups represents variation of the group means around the overall mean. Within groups represents variation of the individual scores around their respective group means. Small significance value of $0.002(<.05)$ indicate group differences. In this case, the significance level 0.002 is less than .05 . At least one of the regions differs from the others:

$$
\begin{aligned}
& \mathrm{F}_{\text {cal }}=4.433 \text { and } \mathrm{F}_{\text {tab }(4,314,0.05)}=3.32, \\
& \text { since } \mathrm{F}_{\text {cal }}>\mathrm{F}_{\text {tab }} .
\end{aligned}
$$

Based on ANOVA test results (3) the hypothesis is accepted at 0.05 level of significance. Post hoc Tukey HSD test applied to find which category of respondents (based on their education level) participated most is e-choupal activities showed that there is a significant difference (Mean difference: 0.614 Sig: 0.002) between the participation level of respondents who have no formal schooling and other degree or diploma holders, participation of respondents who did not get any formal schooling or did schooling up to senior secondary is maximum (refer Fig. 8). 


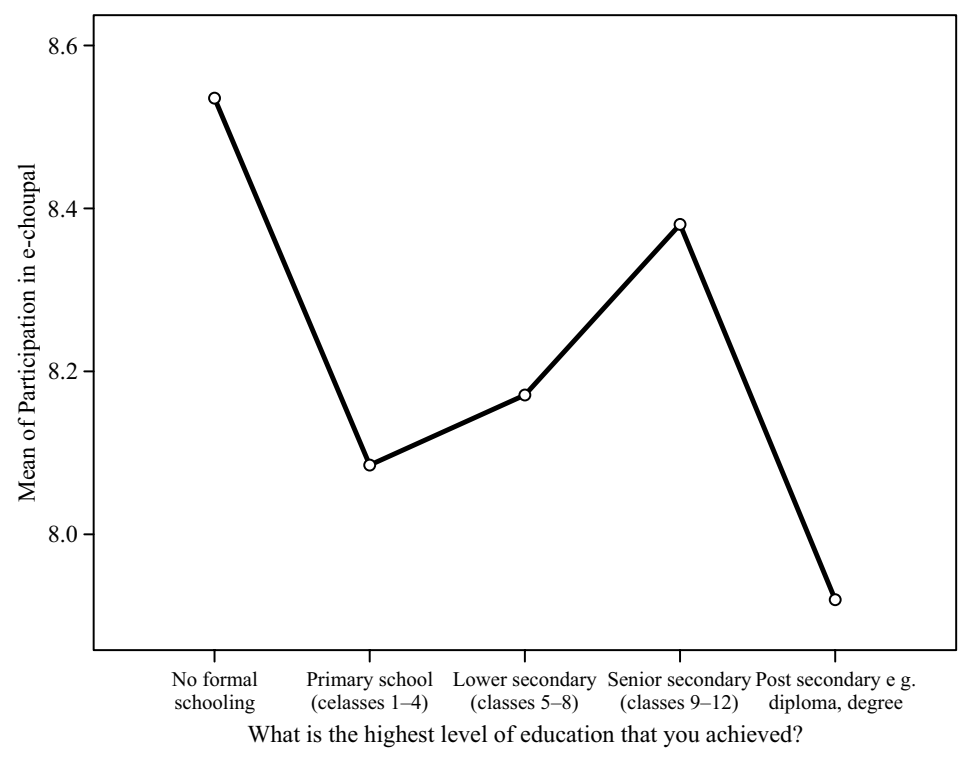

Fig. 8. Means of the participation in E-Choupal of respondents with different education levels

\section{Conclusions}

E-Choupal has definitely achieved a status of a business opportunity development model among rural masses of the largest populated stated on India which shows that these types of models can be replicated by the corporates and governments of various developing economies in Asia and Africa. An intense relationship of "Capability" approach and business opportunity development by e-Choupal got established showing growth in the intensity of relationship as and when the role of models like e-Choupal expands vertically and horizontally in terms of integration in their services and also with the increase in the numbers of people getting connected to such services. Sanchalak definitely plays a crucial role in propelling the innovations and characteristically mobilizing the associations within the said system. Impact of e-Choupal on "Capability" development' of the rural population got proved and the participants of the process whether institutions or people or sanchalaks can use it as a measurement criterion to assess the impact of such interventions and efforts on increase in capability of people in rural areas. This can further be concluded that capability of rural people in terms of growth of business opportunities, income, and social status got influenced by ITC e-Choupal. ICT based business opportunity development interventions got validated through this research but to establish their complete feasibility in developing economies, it may take more time. Sanchalak being a key point in ICT enabled business development opportunity model, the education and regular skill up gradation is required, even collaboration with higher educational institutions for their skill enhancement can solve the purpose. The business model like e-Choupal can work effectively with adequate infrastructure and power supply conditions in the country, else it will reduce the attractiveness of the business model so collaboration with organizations like TATA BP Solar (2012) and other clean energy 
producing organizations must be made. Roping in of more and more social development organizations and government stakeholders is must for rolling e-Choupal type of model in a large geographical area because services and utilization of services is the key to its success wherein all the participants of the process have to monitor, mentor and participate in a meaningful manner to nurture whole of the system. The major concern is related to facilitation of information about market, prices, cutting short of the distribution and procurement chain, building avenues for sale and purchase of any quality and quantity of goods as per the convenience of the farmers for which the effectiveness of the process has to be enhanced through increased reach to masses.

\section{References}

Avgerou, C. 2000. Recognizing alternative rationalities in the deployment of information systems, Electronic Journal of Information System in Developing Countries 3(7): 1-15.

Bowonder, B.; Gupta, V.; Singh, A. 2015. Developing a rural market e-hub. The case study of e-Choupal experience of ITC [online], [cited 28 March 2015]. Available from Internet: http:// www.planningcommission.gov.in/reports/sereport/ser/stdy_ict/4_e-choupal\%20.pdf

Deen-Swarray, M.; Moyo, M.; Stork, C. 2013. ICT access and usage among informal businesses in Africa, INFO 15(5): 52-68. http://dx.doi.org/10.1108/info-05-2013-0025

Dreze, J.; Sen, A. 1995. India: economic development and social opportunity. Delhi: Oxford University Press.

Garai, A.; Shadrach, B. 2006. Taking ICT to every Indian village: opportunities and challenges, One World South Asia 3: 133-141.

Gigler, B. S. 2004. Including the Excluded-Can ICTs empower poor communities? Towards an alternative evaluation framework based on the capability approach. Paper presented at 4th International Conference on the Capability Approach, 5-7 September 2004, Pavia, Italy.

Good, T.; Qureshi, S. 2009. Investigating the effects of microenterprise access and use of ICT through a capability lens: implications for global development, in Proceedings of the Second Annual SIG Glob-Dev Workshop, 2009, Phoenix, USA.

Haq, M. 1995. Reflections on human development. Oxford, London: Oxford University Press.

Indian Tobacco Company (ITC). 2012. India's foremost private sector companies [online], [cited 26 October 2015]. Available from Internet: http://www.itcportal.com/about-itc/profile/index.aspx

Kabongo, J. D.; Okpara, J. O. 2014. ICT possession among Congolese SMEs: an exploratory study, Journal of Small Business and Enterprise Developmen 21(2): 313-326.

http://dx.doi.org/10.1108/JSBED-10-2013-0143

Martinussen, J. 1996. Introduction to the concept of human development, Integrated Farming in Human Development 2: 23-32.

Nussbaum, M. 2003. Capabilities as fundamental entitlements: Sen and social justice, Feminist Economics 9(2/3): 33-59. http://dx.doi.org/10.1080/1354570022000077926

Oosterlaken, I.; Van den Hoven, J.; Kandachar, P.; Mani, M. 2009. Technology and human development: a capability approach [online]. Delphi: Delft University of Technology/Indian Institute of Science. Available from Internet: http://ethicsandtechnology.eu/projects/technology_and_human_development_a_capability_approach/

Prahalad, C. K.; Hammond, A. 2002. What works: serving the poor, profitably, Harvard Business Review [online]. Available from Internet: https://hbr.org/2002/09/serving-the-worlds-poorprofitably 
Sen, A. 1983. Development: which way now? The Economic Journal 93(372): 745-762. http://dx.doi.org/10.2307/2232744

Sen, A. 1984. Resources, values and development. Oxford, London: Blackwell and Cambridge.

Sen, A. 2000. Development as freedom. New York: Oxford University Press.

Sen, A. K. 2004. Capabilities, lists, and public reason: continuing the conversation, Feminist Economics 10(3): 77-80. http://dx.doi.org/10.1080/1354570042000315163

Sharma, V.; Madan, P.; Seth, P. 2011. Capability development of customers: a globally viable business strategy for the coming age, International Journal of Strategic Information Technology and Applications 2(2): 12-22. http://dx.doi.org/10.4018/jsita.2011040102

Szirmai, A. 2005. The dynamics of socio-economic development: an introduction. Cambridge: Cambridge University Press. http://dx.doi.org/10.1017/CBO9780511817342

TATA BP. 2012. Tata BP Solar is a joint venture between Tata Power Company, a pioneer in the power sector in India and BP Solar, one of the largest solar companies in the world [online], [cited 28 November 2015]. Available from Internet: http://www.tatapowersolar.com/

Pankaj MADAN, PhD is a practicing Professor with degrees in Production Engineering, Management and Web Technology. He is a Professor of Management at CENTRUM Catolica, the business school of University of Peru. He has authored 12 books and published papers in the areas on E-Commerce, M-Commerce, TQM and Entrepreneurship.

Vinay SHARMA is MBA from Philippine Christian University and doctorate in Strategic Management. Has around 17 years of Experience and has interest in the areas of Business Opportunity, Development, Market Development, Brand Development, IT enabled Services and Teaching for past eight years. He is presently working as Assistant Professor, with the Department of Management Studies at Indian Institute of Technology, Roorkee, India.

Piyush SETH, PhD from Gurukul Kangri Vishwavidyalaya Haridwar, Uttarakhand. MBA from Institute of Engineering and Technology, Lucknow affiliated to Uttar Pradesh Technical University, Lucknow, Uttar Pradesh. His areas of interests include Poverty Alleviation through Business Development, Market Development, Information and Communication Technology and rural marketing and its association with Amartya Sen's Capability Approach. 